\title{
PERBEDAAN HASIL BELAJAR SISWA YANG DIAJARKAN DENGAN MODEL PEMBELAJARAN KOOPERATIF TIPE STUDENT FACILITATOR AND EXPLAINING DAN MODEL PEMBELAJARAN KONVENSIONAL PADA MATERI STATISTIKA DI KELAS XI SMA NEGERI 1 TNS
}

\author{
Jen Frisilia Tato ${ }^{1 *}$, A. L. Palinussa ${ }^{1}$, N. C. Huwaa ${ }^{1}$ \\ ${ }^{1}$ Program Studi Pendidikan Matematika, Fakultas Keguruan dan Ilmu Pendidikan, Universitas \\ Pattimura.
}

Email: *frisiliajen12@gmail.com

\begin{abstract}
ABSTRAK. Penelitian ini bertujuan untuk mengetahui ada tidaknya perbedaan hasil belajar siswa kelas XI SMA Negeri 1 TNS yang diajarkan menggunakan model pembelajaran kooperatif tipe Student Facilitator and Explaining (SFE) dan model pembelajaran konvensional pada materi statistika. Tipe penelitian yang digunakan adalah penelitian eksperimen dengan desain penelitian Post-Test Only Control Group Design. Populasi dalam penelitian ini adalah 90 siswa dan sampel dalam penelitian ini adalah 44 siswa, dipilih menggunakan purposive sampling (sampel Bertujuan). Instrumen yang digunakan dalam penelitian ini berupa soal tes yang terdiri dari 6 soal uraian untuk tes akhir. Analisis yang digunakan adalah analisis statistik uji $\mathrm{t}$ dan hasil penelitian menunjukan ada perbedaan hasil belajar siswa kelas eksperimen dan kelas kontrol yang diajarkan dengan model pembelajaran kooperatif tipe Student Facilitator and Explaining (SFE) dan model pembelajaran konvensional pada materi statistika. Hal ini dibuktikan dengan hasil perhitungan yang diperoleh yakni, nilai $\boldsymbol{t}_{\text {hitung }}=2,6491$ lebih besar dari nilai $\boldsymbol{t}_{\text {tabel }}=1,682$ dan nilai Sig. (2-tailed) lebih kecil dari nilai $\alpha=0,05$ yakni 0,002 .
\end{abstract}

Kata Kunci: Hasil belajar, model pembelajaran kooperatif tipe student facilitator and explaining (SFE), model pembelajaran konvesional, statistika.

\section{Pendahuluan}

Matematika merupakan ilmu universal yang mendasari perkembangan teknologi modern. Matematika memiliki peran penting dalam berbagai disiplin dan memajukan daya pikir manusia. Untuk menguasai dan menciptakan teknologi di masa depan diperlukan penguasaan matematika yang kuat sejak dini (Ratumanan, 2017:1). Oleh karena itu siswa perlu memiliki kemampuan untuk menguasai, menciptakan dan menghadapi perkembangan teknologi yang selalu berubah dan tidak pasti.

Masalah utama dalam pembelajaran pada pendidikan formal dewasa ini adalah masih rendah daya serap siswa. Hal ini tampak dari rerata hasil belajar siswa yang senantiasa masih sangat memprihatinkan. Prestasi ini tentunya merupakan hasil kondisi pembelajaran yang masih bersifat konvesional dan tidak menyentuh ranah dimensi siswa itu sendiri (Trianto, 2014: 6). Sejalan dengan itu berdasarkan observasi yang dilakukan peneliti di SMA Negeri 1 TNS ditemui bahwa proses pembelajaran dikelas masih berpusat pada guru yang memberikan pengajaran kepada siswa sehingga siswa cendrung kurang aktif.

Menurut Susanto (2013: 191-192), rendahnnya prestasi belajar matematika siswa, tentu banyak faktor yang menyebabkan, misalnya masalah klasik tentang penerapan metode pembelajaran matematika yang masih terpusat pada guru, sementara siswa cenderung pasif. Faktor klasik lainnya, ialah penerapan model pembelajaran konvensional, yakni ceramah, tanya jawab, dan pemberian tugas. Sistem pengajaran yang demikian ini menyebabkan siswa tidak berpartisipasi aktif dalam mengikuti pembelajaran.

Hasil Observasi dan wawancara dengan guru matematika di sekolah ditindak lanjuti dengan menggunakan tes identifikasi dengan memberikan soal statistika di kelas XI SMA Negeri 1 TNS, terlihat bahwa siswa masih keliru dalam menyelesaikan soal yaitu siswa tidak menggunakan rumus dalam mengerjakan soal yang diberikan dan menyelesaikan soal tidak secara bertahap.

Lemahnya kemampuan siswa dalam memahami materi statistika merupakan salah satu faktor yang dapat mempengaruhi rendahnya hasil belajar siswa. Untuk itu, perlu adanya antisipasi dengan cara mencari solusi yang tepat. Oleh karena itu, diperlukan suatu model pembelajaran yang dapat memberi peluang kepada siswa melakukan aktifitas dalam kegiatan belajar mengajar khususnya untuk pelajaran matematika. 
Model pembelajaran kooperatif tipe Student Facilitator and Explaining (SFE) merupakan suatu model yang dapat mengatasi masalah di atas karena siswa dituntut untuk belajar mempresentasikan ide atau pendapatnya pada teman yang lain. Model pembelajaran Student Facilitator and Explaining menjadikan siswa sebagai fasilitator dan diajak berpikir secara kreatif sehingga menghasilkan pertukaran informasi yang lebih mendalam dan lebih menarik serta menimbulkan rasa percaya diri pada siswa. Peran siswa sebagai fasilitator dalam model ini yaitu merencanakan bagaimana cara mereka mengajari materi yang sedang dipelajari kepada satu sama lain dan menyampaikannya secara lisan melalui bagan/peta konsep atau yang lainnya kepada anggota kelompok yang lain (Jhonson, 2010: 117).

Rumusan masalah penelitian ini adalah Bagaimana hasil belajar siswa yang diajarkan dengan model pembelajaran kooperatif tipe Student Facilitator and Explaining dan model pembelajaran konvensional pada materi statistika di kelas XI SMA Negeri 1 TNS dan Apakah ada perbedaan hasil belajar siswa yang diajarkan dengan model pembelajaran kooperatif tipe Student Facilitator and Explaining dan model pembelajaran konvensional pada materi statistika di kelas XI SMA Negeri 1 TNS ?

\section{Metode}

Tipe yang digunakan dalam penelitian ini adalah tipe penelitian eksperimental (Experimental Research) dengan desain penelitian adalah Post test only control group design. Populasi dalam Penelitian ini adalah seluruh siswa kelas XI IPA SMA Negeri 1 TNS yang terdiri dari 4 kelas. Sampel yang diambil dalam penelitian ini adalah 2 kelas yang diambil dengan memperhatikan kemampuan rata-rata siswa dari dua kelas yang relatif sama yaitu kelas XI IPA 3 dengan nilai rata- rata ulangan harian 77,86 dan kelas XI IPA 4 dengan nilai rata-rata ulangan harian 78,18 .

Dalam penelitian ini dikembangkan Rencana Pelaksanaan Pembelajaran (RPP) untuk masing-masing kelas. Untuk kelas eksperimen dikembangkan RPP sesuai model pembelajaran SFE untuk 4 (empat) pertemuan, demikian pula untuk kelas kontrol dikembangkan RPP untuk 4 (empat) pertemuan dengan cakupan atau luasan materi yang sama. Selain itu dikembangkan pula Lembar Kerja Siswa (LKS) dan bahan ajar statistika sesuai dengan kebutuhan penerapan model pembelajaran kooperatif tipe SFE. Juga dikembangkan instrument tes ang digunakan untuk mengukur hasil belajar siswa pada kedua kelas.

Pelaksaan pembelajaran pada masing-masing kelas, dilaksanakan mengacu pada RPP yang telah disusun dan divalidasi oleh pakar. Pada akhir kegiatan pembelajaran (setelah pertemuan keempat selesai) dilaksanakan tes kepada kedua kelas. Hasil tes selanjutnya dianalisis menggunakan analisis statistik deskriptif. Sebelum dilakukan uji-t perlu dilakukan uji prasyarat sampel degan menggunakan uji normalitas dan uji homogenitas. Data diolah dengan menggunakan bantuan software SPSS versi 25.0.

\section{Hasil Penelitian}

\subsection{Analisis Deskriptif}

Pelaksanaa pembelajaran menggunakan model pembelajaran student facilitator and explaining pada kelas eksperimen dlaksanakan dalam 4 pertemuan. Setiap tahapan pembelajaran sesuai sintaks, berlangsung dengan baik dan lancar sesuai dengan yang direncanakan pada RPP. Aktiitas pembelajaran didukung dengan bahan ajar dan Lembar Kerja Siswa (LKS). Aktivitas siswa dalam kegiatan kelas maupun dalam kegiatan kelompok ketika membahas materi dan mengerjakan LKS berlangsung dengan baik. Saat siswa belajar dalam kelompok kecil mempelajari bahan ajar, membuat peta konsep dan mengerjakan LKS, guru berjalan berkeliling memperhatikan aktivitas kelompok, dan memberikan bantuan penjelasan ketika kelompok mengalami kesulitan.

Pada kelas kontrol akni kelas yang menggunakan model pembelajaran konvensional, kegiatan belajar mengajar juga berlangsung selama 4 pertemuan. Pembelajaran dengan guru menjelaskan materi kepada siswa juga berlangsung dengan baik sesuai dengan langkah-langkah model pembelajaran konvensional.

Setelah pembelajaran dilakukan pada kedua kelas sesuai RPP untuk masing-masing kelas, pada pertemuan kelima dilakukan tes hasil belajar pada kedua kelas. Tes dilakukan menggunakan soal test akhir yang telah divalidasi. Adapun hasil tes masing-masing kelas adalah sebagai berikut. 
Tabel 1. Hasil Belajar Siswa

\begin{tabular}{|c|c|c|c|}
\hline \multirow{2}{*}{ Kualifikasi } & \multirow{2}{*}{ Nilai } & \multicolumn{2}{|c|}{ Jumlah Siswa } \\
\cline { 3 - 4 } & & $\begin{array}{c}\text { Kelas } \\
\text { Eksperimen }\end{array}$ & Kelas Kontrol \\
\hline Sangat tinggi & $x \geq 90$ & 2 & 0 \\
\hline Tinggi & $75 \leq x<90$ & 10 & 4 \\
\hline Sedang & $60 \leq x<75$ & 6 & 9 \\
\hline Rendah & $40 \leq \mathrm{x}<60$ & 4 & 5 \\
\hline Sangat rendah & $x<40$ & 0 & 4 \\
\hline
\end{tabular}

Dari tabel diatas, terlihat bahwa pada kelas eksperimen terdapat 2 siswa memiliki kemampuan sangat tinggi dan 10 siswa dengan kemampuan tinggi. Sedangkan pada kelas kontrol hanya terdapat 4 siswa yang memiliki kemampuan tinggi. Pada kelas eksperimen, Iterdapat 6 siswa yang memiliki kemampuan sedangkan untuk kela kontrol 9 orang. Pada kelas eksperimen, terdapat 4 siswa yang memiliki kemampuan rendah atau sangat rendah, sedangkan pada kelas kontrol, siswa dengan kemampuan rendah jauh lebih tinggi yakni 9 orang. Dari perhitungan nilai rata-rata hasil belajar siswa kelas eksperimen dan kelas kontrol diperoleh hasil sebagaimana di sajikan pada tabel 2 berikut:

Tabel 2. Rata-rata Hasil Belajar Siswa

\begin{tabular}{|c|c|}
\hline Kelas & Rata-Rata \\
\hline Eksperimen & 71,5164 \\
\hline Kontrol & 56,9541 \\
\hline
\end{tabular}

Tabel 2 diatas memperlihatkan bahwa nilai rata-rata siswa kelas eksperimen lebih tinggi bila dibandingkan dengan nilai rata-rata siswa kelas kontrol. Selisih nilai rata-rata kedua kelas yaitu 14,5623. Dengan demikian, baik dari tabel 1 maupun tabel 2 diatas dapat disimpulkan bahwa pembelajaran dengan menggunakan model kooperatif tipe SFE memberikan hasil yang lebih baik bia dibandingkan dengan pembelajaran konvensional.

\subsection{Hasil Uji Hipotesis}

Sebelum dilakukan uji hipotesis, perlu dilakukan terlebih dahulu analisis prasyarat. Analisis prasyarat dimaksud adalah uji normalitas dan uji homogenitas. Hasil uji normalitas hasil belajar pada kedua kelas menggunakan rumus Chi Square disajikan pada tabel 3 berikut.

Tabel 3. Hasil Uji Normalitas

\begin{tabular}{|c|c|c|c|c|}
\hline Kelas & $x_{\text {hitung }}^{2}$ & $x_{\text {tabel }}^{2}$ & Sig. & Kesimpulan \\
\hline Eksperimen & 7,272858 & 22,36203 & 0,888 & Terima $H_{0}$ \\
\hline Kontrol & 4,000018 & 21,02607 & 0,983 & Terima $H_{0}$ \\
\hline
\end{tabular}

Dari tabel di atas terlihat bahwa pada kelas eksperimen, diperoleh nilai $x_{\text {hitung }}^{2}=7,272858$ lebih kecil dari $x_{\text {tabel }}^{2}=22,36203$ dan nilai Sig. lebih besar dari nilai $\alpha=0,05$ yaitu 0,888, maka dapat disimpulkan bahwa kelas eksperimen berasal dari populasi yang berdistribusi normal. Tabel diatas juga memperlihatkan bahwa pada kelas kontrol diperoleh $x_{\text {hitung }}^{2}=4,000018$ lebih kecil dari nilai $x_{\text {tabel }}^{2}=21,02607$ dan nilai Sig. lebih besar dari nilai $\alpha$ $=0,05$ yaitu 0,983 , maka disimpulkan bahwa kelas kontrol berasal dari pupulasi yang berdistribusi normal.

Selanjutnya dilakukan uji homogenitas untuk menentukan apakah kedua varians homogeny ataukah tidak. Hasil pengujian dimaksud disajikan pada tabel 4 berikut. 
Tabel 4. Hasil Uji Homogenitas

\begin{tabular}{|c|c|c|c|c|}
\hline Kelas & $\mathrm{F}_{\text {hitung }}$ & $\mathrm{F}_{\text {tabel }}$ & Sig. & Kesimpulan \\
\hline $\begin{array}{c}\text { Eksperimen } \\
\text { dan Kontrol }\end{array}$ & 1,973874 & 2,0842 & 0,054 & Terima $H_{0}$ \\
\hline
\end{tabular}

Dari tabel di atas terlihat bahwa nilai $F_{\text {hitung }}=1,97387$ lebih kecil dari nilai $F_{\text {tabel }}=2,0842$ dan nilai Sig. lebih besar dari nilai $\alpha=0,05$ yakni 0,054 . Dengan demikian $H_{0}$ diterima. Ini berarti bahwa kedua populasi memiliki varians yang homogeny.

Karena data hasil belajar memenuhi ketentuan berdistribusi normal dan ketentuan homogenitas varians, maka dapat dilanjutkan dengan uji t, sebagai salah satu uji statistik inferensial. Hasil uji dimaksud dapat disajikan pada tabel 5 berikut.

Tabel 5. Hasil Uji Hipotesis

\begin{tabular}{|c|c|c|c|c|}
\hline Kelas & $t_{\text {hitung }}$ & $t_{\text {tabel }}$ & Sig. & Kesimpulan \\
\hline $\begin{array}{l}\text { Eksperimen } \\
\text { dan Kontrol }\end{array}$ & 2,6491 & 1,682 & 0,002 & Tolak $H_{0}$ \\
\hline
\end{tabular}

Dari tabel diatas dapat dilihat bahwa nilai $t_{\text {hitung }}=2,6491$ lebih besar dari nilai $t_{\text {tabel }}=1,682$ dan nilai Sig. lebih kecil dari nilai $\alpha=0,05$ yakni 0,002 . Hal ini menunjukan bahwa pada taraf signifikansi $\alpha=5 \% H_{0}$ ditolak dan $H_{1}$ diterima. Dengan demikian dapat disimpulkan ada perbedaan hasil belajar siswa antara kelas eksperimen yang diajarkan dengan model pembelajaran Student Facilitator and Explaining (SFE) dan kelas kontrol yang diajarkan menggunakan model pembelajaran konvensional.

\subsection{Pembahasan}

Berdasarkan pemberian perlakuan yang berbeda pada kedua kelas tersebut, maka hasil akhir yang diperoleh pun berbeda pula. Hal ini Nampak pada perbedaan nilai rata-rata yang signifikan dari hasil belajar siswa yaitu untuk kelas yang menggunakan model pembelajaran kooperatif tipe Student Facilitator and explaining (SFE) memperoleh nilai rata-rata 71,5164 lebih tinggi dari kelas yang menggunakan model pembelajaran konvensional yang memperoleh nilai rata-rata 56,9541. Hasil yang diperoleh menunjukkan bahwa model pembelajaran kooperatif tipe student facilitator and explaining (SFE) merupakan model pembelajaran yang lebih baik dibandingkan model pembelajaran konvensional. Trianto (2007: 41) mengemukakan bahwa model pembelajaran Student Facilitator and Explaining merupakan salah satu tipe pembelajaran kooperatif yang menekankan pada struktur khusus yang dirancang untuk mempengaruhi pola interaksi siswa dan memiliki tujuan untuk meningkatkan penguasaan materi. Di dalam kelas kooperatif siswa belajar bersama dalam kelompok-kelompok kecil yang terdiri dari 4-5 orang siswa yang sederajat tetapi berbeda kemampuan, jenis kelamin, suku/ras, dan satu sama lain saling membantu. Tujuan dibentuknya kelempok tersebut adalah untuk memberikan kesempatan kepada semua siswa untuk dapat terlibat secara aktif dalam proses perpikir dan kegiatan belajar mengajar. Berbeda dengan Ratumanan (2015: 15) bahwa, proses transfer informasi menjadi kondisi yang dominan dalam model pembelajaran konvensional. Sehingga partisipasi siswa rendah karena siswa hanya diberikan kebebasan untuk bertanya mengenai materi yang dijelaskan oleh guru.

Hasil belajar siswa yang diperoleh kelas eksperimen berdasarkan penilaian acuan patokan pada tabel 4.2 terlihat bahwa siswa pada kelas yang memperoleh kualifikasi sangat tinggi berjumlah 2 siswa dan kualifikasi tinggi berjumlah 10 siswa. Hal tersebut disebabkan karena dalam proses pembelajaran mereka terlihat aktif, bersemangat, berkerja sama dalam kelompok untuk mempresentasikan kembali materi melalui bagan atau peta konsep yang telah mereka buat dalam kelompok masing-masing dengan memperhatikan bahan ajar yang diberikan sebagai patokan dalam mengerjakan LKS dengan baik sehingga penguasaan siswa terhadap materi statistika sangat baik. Untuk kualifikasi sedang berjumlah 6 orang dan kualifikasi rendah berjumlah 4 orang, hal tersebut dikarenakan dalam proses pembelajaran mereka kurang aktif dalam kelompok sehingga penguasaan materi belum terlalu baik dan adanya kesalahan yang dilakukan siswa dalam proses perhitungan maupun penulisan rumus. Sedangkan untuk kualifikasi sangat rendah tidak ada. 
Sedangkan pada kelas kontrol yang memperoleh kualifikasi sangat baik tidak ada dan kualifikasi baik berjumlah 4 siswa, hal ini disebabkan karena hanya beberapa siswa yang aktif dan serius dalam proses pembelajaran. Untuk kualifikasi sedang berjumlah 9 siswa dan kualifikasi rendah berjumlah 5 siswa, hal ini disebabkan karena selama proses pembelajaran banyak siswa terlihat diam dan hanya menerima pelajaran dari guru tanpa bertanya. Selanjutnya untuk kualifikasi sangat rendah berjumlah 4 siswa, hal ini disebabkan karena ketika guru mengajar siswa tidak memperhatikan malah bermain, tidak mencatat semua materi maupun latihan soal yang dibahas sehingga menyebabkan hasil belajar siswa sangat rendah.

Setelah memperoleh hasil tes akhir dari kedua kelas, maka dilakukan perhitungan statistik untuk mengetahui ada tidaknya perbedaan yang signifikan pada hasil belajar melalui uji berbedaan rata-rata atu uji-t dengan menggunakan SPSS 25.0. hasil dari SPSS menunjukkan bahwa $\alpha=0,05$ lebih besar dari Sig. (2-tailed) $=0,002$. Hal tersebut menyebabkan $\mathrm{H}_{0}$ ditolak dan $\mathrm{H}_{1}$ diterima, ang berarti bahwa ada perbedaan hasil belajar siswa menggunakan model pembelajaran Student Facilitator and Explaining (SFE) dan model pembelajaran konvensional pada materi statistika.

Hasil penelitian ini sesuai dengan penelitian terdahulu, yaitu penelitian yang dilakukan Kakerissa (2015). Hasil penelitian Ruhulessin menunjukkan bahwa terdapat perbedaan hasil belajar yang signifikan antara siswa yang diajarkan dengan menggunakan model pembelajaran Student Facilitator and Explaining (SFE) dan model pembelajaran konvensional. Hal ini berdasarkan hasil SPSS diperoleh $\alpha=0,05$ lebih besar dari sig. $(2-$ tailed $)=$ 0,003 .

\section{Kesimpulan}

Berdasarkan hasil penelitian yang telah dideskripsikan diatas, dapat disimpulkan bahwa Hasil belajar siswa pada kelas eksperimen lebih besar dari kelas kontrol yaitu 72, 5164, sedangkan untuk kelas kontrol sebesar 56,9541 dan ada perbedaan hasil belajar siswa menggunakan model pembelajaran koopertif tipe Student Facilitator and Explaining (SFE) dan model pembelajaran konvensional pada materi statistika.

\section{Daftar Pustaka}

Jhonson. 2010. Cooperative Learning. Bandung: Alfa Beta

Kakerissa, T. Y. 2015. Perbedaan Hasil Belajar Siswa Kelas XII SMA Negeri 7 Ambon Yang Diajarkan dengan Model Pembelajaran Student Facilitator and Explaining dan Model Pembelajaran Konvensional Pada Materi Matriks. FKIP Universitas Pattimura. (SKRIPSI)

Ratumanan, T. G., 2015. Belajar Dan Pembelajaran Serta Faktor-Faktor Yang Mempengaruhinya. Surabaya: Unesa University Press.

Ratumanan, T. G., \& Matitaputty, C. 2017. Belajar Dan Pembelajaran Matematika.Bandung: ALFABETA

Ruhulessin, S., Ratumanan, T., \& Tamalene, H. (2019). Perbedaan Hasil Belajar Siswa Kelas X SMA Menggunakan Model Pembelajaran Kooperatif Tipe Student Facilitator and Explaining (SFE) dan

Model Pembelajaran Konvensional Pada Materi Trigonometri. Jurnal Pendidikan Matematika (Jupitek), 2(1), 1-6

Susanto, A. 2013. Teori Belajar Dan Pembelajaran Di Sekolah Dasar. Jakarta: Kencana

Trianto. 2007. Model-model Pembelajaran Inovatif berorientasi kostrktivisme. Jakarta: Prestasi Pustaka

Trianto. 2014. Model Pembelajaran Terpadu : Konsep, Strategi, dan Implementasinya dalam Kurikulum Tingkat Satuan Pendidikan (KTSP). Jakarta: Bumi Aksara 